\title{
Implementing Total Quality Management in Education: Compatibility and Challenges
}

\author{
Abu Saleh Md. Sohel-Uz-Zaman', Umana Anjalin 2,3 \\ ${ }^{1}$ School of Business \& Economics, United International University, Dhaka, Bangladesh \\ ${ }^{2}$ University of Tennessee, Knoxville, USA \\ ${ }^{3}$ Department of Business Administration, University of Asia Pacific, Dhaka, Bangladesh \\ Email: sohelzaman@gmail.com, uanjalin@vols.utk.edu
}

How to cite this paper: Sohel-Uz-Zaman, A.S.Md. and Anjalin, U. (2016) Implementing Total Quality Management in Education: Compatibility and Challenges. Open Journal of Social Sciences, 4, 207-217. http://dx.doi.org/10.4236/jss.2016.411017

Received: October 20, 2016 Accepted: November 23, 2016 Published: November 30, 2016

\begin{abstract}
Quality education is a great concern in many societies across the world. In a highly competitive education sector, the success of academic institutions depends on the quality of education. Educationalists, policy makers, scholars, and researchers are showing their sincere interest towards the total quality management (TQM) as it is recognized as an effective management philosophy for continuous improvement, customer satisfaction, and organizational excellence. Since this concept was initially developed in the manufacturing sector, therefore, there is a great deal of suspicion whether this philosophy is applicable in education. In this connection, the main objective of this study is to investigate the compatibility of TQM with education. At the same time, this study would try to identify key challenges in implementing TQM in education. It is assumed that this study would be able to draw a meaningful conclusion regarding the applicability of TQM in education as well as to create an awareness regarding those challenges which may create obstacles in implementing TQM in education.
\end{abstract}

\section{Keywords}

Total Quality Management (TQM), Education, Compatibility, Challenges,

Continuous Improvement, Quality Culture

\section{Introduction}

Total Quality Management (TQM) is recognized as an effective management philosophy which is used as a strategy for business excellence. Although the concept of total quality management was advocated by Dr. W. Edwards Deming in the late1950's in the USA; however, Japan was the first national who embraced this concept to recover their 
economy after the World War II. The success of TQM in Japan made this concept famous in many countries across the world. Originally, the concept was developed for manufacturing organizations; later on, it gained popularity to other service institutions, including bank, insurance, non-profit organizations, health care and so on. Lunenburg comments that TQM is also relevant to corporations, service organizations, universities, and elementary and secondary schools [1]. Now, TQM is recognized as a generic management tool and applicable to any organization.

According to Koslowski, in this age of intense competition, quality education is a major concern [2]. The pressure and demand for quality education are increasing. All concerned parties of the education are actively considering implementing TQM in education because it is believed that quality education is one of the fundamental building blocks of economic development. Regarding the applicability of TQM in education, there is a serious debate since this concept was initially developed for manufacturing organizations. It is essential to resolve this problem. While conducting an initial investigation it was also revealed that there are critical challenges in implementing TQM in education. It is also imperative to explore the nature of those challenges so that academic institutions can take proper measure proactively while pursuing TQM in education.

\section{Objectives and Scope of the Study}

The core objective of this study is to assess the compatibility of TQM with education. At the same time, this study would try to identify those challenges which may impede the application of TQM in education. While attaining these objectives this study would make a special focus on the term TQM so that the characteristics and the potential benefits of adopting TQM can be visualized to all. In this paper education refers to primary, secondary and tertiary level education, including professional and vocational education, etc.

\section{Methodology}

The qualitative methodology has been chosen for this study. This exploratory approach would give an opportunity to understand and clarify the main problem of this study. Data and information for this study are collected through extensive literature, interviewing experts and personal experience.

\section{Total Quality Management: Definition, Characteristics and Benefits}

Total Quality Management is a management approach that was instigated in the 1950s and has gradually become popular since the early 1980s. The term 'quality' is at the core of this philosophy. While defining total quality management, scholars took the opportunity to present their perceptions regarding this term in numerous ways; as a result, a good number of definitions appear before us with different connotations. Crosby states that quality management is a methodical way of ensuring that organized activities hap- 
pen the way they are planned [3]. Short \& Rahim define TQM is a proactive approach, to confirm quality into the product, service and design of the process and then to continually improve it [4]. According to these definitions, TQM is a plan, a systematic approach to ensure quality and continuous improvement. Deming describes TQM is a never-ending cycle of progress in the system of production should change into gaining better performance and quality standards for the product [5]. Yang perceives TQM is a set of practices that focuses on the systematic improvement, satisfying the customers' needs, and decreasing rework [6]. TQM is a system and set of practices which are aimed at relentless quality improvement and better business performance.

TQM views an organization as a collection of interrelated processes. It (TQM) is a method by which management and employees are involved in continuous improvement of the production of goods and services. Goetsch and Davis opine that TQM consists of relentless improvement activities, involving everybody in the business in a totally integrated effort towards improving performance at every level [7]. Vinni comments TQM creates such environment in which all the assets are used ingeniously and effectively in order to provide quality service the institution needs to adapt in this fast paced world [8].

According to Witcher, TQM is the combination of three terms-Total: meaning that one is involved, including customer and suppliers; Quality: indicating that customer needs are met exactly; and Management: indicating that senior executives are committed [9]. Oakland expresses TQM as an approach involving the whole organization for understanding each activity of each individual at each management layer [10]. TQM strives to integrate all organizational functions (marketing, finance, design, engineering, and production, customer service, etc.) to focus on meeting customer needs and organizational objectives. Escrig considers TQM as a strategic action that focuses on managing the total organization to provide products or services that fulfill their customer requirements by utilizing all resources [11]. TQM is the holistic management approach that incorporates all the organizational activities to satisfy customers' needs and achieving overall organizational objectives as outlined by Kumar et al. [12].

Spanbaueridentifies TQM as a pragmatic model focuses on service to others [13]. Yudof and Busch-Vishniacstate that TQM embraces the norm that organizations should listen to their customers, continually evaluate how well they are responding to their needs and initiate change in order to meet or exceed the desires of the customers [14]. The message is clear that business is improved by the satisfied customers and it is ruined by the dissatisfied customers as expressed by Anderson and Zemke [15]. Lee and Hwan remark customer satisfaction is highly related to service quality and it is an important aspect for service organizations [16]. The observation of Wani and Mehraj is very much profound; according to them, TQM is a management philosophy which creates a customer-driven learning organization, devoted to total customer satisfaction through continuous improvement in the effectiveness and efficiency of the organization and its processes [17]. In TQM customer is an exclusive issue and customer satisfaction is considered as a major source of business success. 
TQM advocates about the people development very explicitly because business excellence largely depends on the extent employees of an organization are capable in their respective fields. TQM uses employee capabilities in all activities and processes and makes collaboration feasible and real as comprehended by Schargel [18]. It leads continuous improvement of the capabilities of the employees.

TQM promotes a quality culture because it can ensure improved product and service quality. Gaither believes that TQM is the process of changing the basic culture of an organization and redirecting it towards superior product or service quality [19]. Yusof and Aspinwall state that TQM helps in creating a culture of trust, participation, teamwork, quality-mindedness, enthusiasm for continuous improvement, constant learning and as a result, a working culture that contributes towards a firm's success and existence [20]. In a TQM effort, all members of an organization participate in improving processes, products, services, and the culture in which they work.

Ishikawa emphasizes on the relevance of total quality control to boost organizational performance; according to him, quality initiatives should go beyond the product and service; entire organization is with the jurisdiction of TQM which will result in enhanced business performance [21]. As specified by British Standard Institution, TQM is composed of a "management doctrine and company patterns which intent to rein the human and material resources of an organization in the most efficient way to attain the goal of the organization" [22].

From these definitions, it is easily possible to identify the essential characteristics as well as the significant offerings of TQM, such as: continuous improvement; integration of people, functions and resources; systematic and structured approach; quality control at every level of the organization and at every step of the operating process; developing human and organizational capabilities; efficient utilization of resources; people participation; customer satisfaction; creating a quality culture and so on. In order to enjoy these benefits academic institutions are inclined to espouse TQM into their process.

\section{Compatibility of TQM with Education}

Michael et al. comment that TQM can be defined as a general management philosophy and a set of tools which allow an institution to pursue a definition of quality and a means for achieving quality, with quality being a continuous improvement as determined by customers' satisfaction with the services they have received [23]. It indicates the flexible aspect of TQM, i.e. it is applicable to any organization and subject to adjustment as per merit of the situation. With the help of TQM, an academic institution would be able to develop its own definition of quality, benchmark, and quality improvement practices in the light of customers' requirement.

Meirovich and Romarobserve that the findings of the literature on the usefulness of TQM in education are differing [24]. There are some authors who are very much confident about the applicability of TQM in education. According to Srivanci, they believe that the values of TQM are similarly appropriate in higher education [25]. TQM principles are compatible with higher education as mentioned by Helms and Key [26] and 
Venkatraman [27]. The finding of James and James is very noteworthy; they opine that TQM is naturally relevant to higher education, because it is a process oriented approach that is designed in increasing productivity, decreasing costs and improving quality [28]. Deming enunciates that the adoption of TQM will help institutions of higher education to maintain their competitiveness, eliminate inefficiencies in the organization, help to concentrate on the market needs, attain high performance in all areas, and fulfill the needs of all stakeholders [29]. Tribus believes that education can be improved through quality management [30]. Peak maintains that TQM improves educational organizations in many ways, such as improving education process, making the educational environment motivating, improving educational curriculum, boosting the speed of training services and reducing costs [31]. TQM is a way of achieving and maintaining excellence in higher education as realized by Eriksen [32]. Dobyns and Crawford-Mason comment that whatever the determining incentive, where quality management has been implemented in education, it has made an enormous difference as mentioned [33]. According to De Jager and Nieuwenhuis, even though TQM developed within the manufacturing environment, the benefits are equally applicable to service organizations such as higher education institutions [34]. Murad and Rajesh perceive TQM is a general management philosophy and a blend of various tools which induce educational institutions to pursue a description of quality and the means to achieve it [35].

Others believe that TQM is to some extent applicable in education. TQM values are only somewhat useful in a dynamic and changing environment which is a characteristic of modern higher education as observed by Koch and Fisher [36], and Houston [37]. Although higher education institutions are not like companies but, some of the basic principles and tools are applicable as these are instruments at the service institutions and their governance and management boards subject to the institution's academic mission, goals and strategies as noticed by Dill [38] and Harvey [39]. In two different studies by Venkatraman and Peat et al. it has been found that TQM is a managerial instrument to resolve the issues associated with services as well as tactics in the academic industry and it can conform to the standard the education industry [27] [40].

According to Williams, continuous quality improvement; quality consistency; participation of academics, students and non-academic staff; satisfaction of the clients; and the existence of management procedures that reinforce quality are a number of quality management programs that nobody would consider irrelevant in the context of higher education [41]. Arcaro opines that quality can create an ambiance where educationalists, parents, government officials, community representatives, and business leaders work jointly to deliver students with the resources they need to meet current and future academic, business, and societal needs [42]. Bayraktar et al. reveal that a number of TQM elements have a critical role in process improvement including, "leadership", "vision", "measurement and evaluation", "process control and improvement", "program design", "quality system improvement", "employee involvement", "recognition and reward", "evaluation and training", "student focus", and "other stakeholder focus" in 
higher education [43].

A good number of scholars find that some TQM tools and techniques are convincingly suitable in education. For example, Sirvancimentions that the use of quality function deployment (QFD) which is used to incorporate the preference of customers and other stakeholders in program design [25]. Quinn et al. discuss the application of Six Sigma, Service Quality (SERVQUAL), ISO9000, and TQM in higher education [44]. It has the capacity to provide practical solutions, positive results in academic and administrative functions.

From the abovementioned discussion, it is clear that TQM is credibly compatible with the education. Nevertheless, in this connection the remark of Sousa and Voss is quite thought provoking; they comment that TQM principles are not universally applicable across all contexts but are contingent on contextual factors [45] [46]. It implies that TQM tools and techniques are subject to fine tuning while applying in education.

\section{Key Challenges in Implementing TQM in Education}

There is no doubt that TQM has full potential to serve education. It must not be taken as granted that there are no challenges or barriers in implementing TQM in education. Some educators believe that philosophy which is developed for business may not be appropriate for service organization like educational institutions. The schools or other type of academic institutions are very much different with a different ethos and characteristics that made difficult, or even impossible to implement a philosophy which has been derived from industry [47] [48] [49] [50]. Rosa et al. state that the terms such as product, client, empowerment, or even strategy, reengineering do not easily correspond in higher education institutions [51].

The biggest obstacle could be the commitment from the parties involved with education system, especially the top management and teachers. Brown et al. notice that lack of top management commitment affects TQM efforts negatively, which is one of the main reasons of failure of TQM efforts [52]. According to Massy, the extreme resistance to quality process improvement comes from professors who consider it is just another business-oriented craze; a typical mindset may undermine the effectiveness of TQM is education[50]. The role of individual, particularly the teachers are often informal and less bureaucratic in traditional education system. On the other hand, Koch and Fisher observe that TQM approach seems to be more administrative and bureaucratic; there is a tendency to produce relentless meetings, generate enormous amounts of paper, and delay or escape critical decision making [36].

There is a long debate about the definition of quality in education. Sarrico et al. state that quality can have multiple meaning in higher education and this variety has considerable influences on the development of methods and instruments of measuring quality; and this variety also can create different stakeholders for the higher education institutions [53]. Houston mentions that the way the definition of quality is given based on the customers' needs and expectations in business and industry environments is not totally appropriate for education [54]. Overall, this term (quality) may create a complex 
situation for the academic institutions.

The term customer may be very easy to define in manufacturing or business organizations. However, defining and identifying customer is a challenge in education. Ali and Shastri comment that vagueness in customer identification also creates obstacles in TQM implementation [55]. According to Houston, the definition (customer) prevails in industry or business environment which based on the idea of satisfying customers' needs and expectations, is a problematic one in education [54]. Education has multitude interested parties. In the case of elementary and high school level, it is relatively easy to define; parents are the customers and students are the consumers. Youssef et al. find that the customers of higher education are much more diverse and not so easily defined [56]. This situation is complicated in the case of tertiary level of education. A student can be both the consumer and customers if he or she pays his or her tuition fees. In the job market, employer organizations are also the customers. In the case of scholarship students, sponsors are the customers. As a whole, the state is also a customer. According to Srivanci, without a precise definition of customer and a customer focus, quality efforts may be easily diffused [25].

Seymour identifies a number of reasons for unsuccessful application of TQM in higher education, such as resistance to change; lacking of administration commitment; high time investment due to personal training; difficulty in applying TQM tools to higher education institutions; insufficient experience of team leaders and staff in teamwork; the anxieties of higher education institutions have with their own results not being sufficient enough [47].

Koch acknowledges a wide range of reasons, these are: lost in focus, i.e. TQM tends to put more emphasizes on non-academic activities (e.g. bill collection, check writing, admissions applications, and physical plant inventory) rather than core academic activities (e.g. curriculum development; teaching and learning style, tuition fees, student welfare etc.); resistance from the faculty members as it (TQM) impedes their authority and freedom, violate the confidentiality related to assessment, promotion, salary and so forth and practice of teamwork in education process as these are not consistent with the traditional teaching process; and defining customers and measuring outcomes are two major difficulties in implementing TQM in education since a wide range of customers (like students, parents, researchers, alumni, business firms and so on) are involved in higher education so it very difficult who are the real customers in education, it is equally difficult to measure the outcomes of quality initiatives [57].

Rosa and Amaral also mention a number of barriers in implementing TQM in education: the absence of effective communication channels; the problem in measuring higher education institutions results; the co-existence of multiple purposes and objectives for higher education institutions; the emphases in the individualism and significant degree of internal competition; the bureaucratic decision-making process; and the lack of a strong leadership, highly committed to the ideas and principles it wants to apply and capable of involving all the institution's members [58]. Dale, et al. notice some critical obstacles such as: ineffective leadership; obstruction to change; contradictory 
policies; inappropriate organizational structure; and poor management of the change process are other shortcomings in implementing TQM [59]. Kosgeidetectsa number of challenges in this regard, too; these are: lack of commitment by the management and some workforce, school's organizational culture, poor documentation, inadequate training of staff, and ineffective communication [60].

\section{Conclusion}

This study does not offer any framework or guidelines what will make implementing TQM successful in an organization; rather it is involved in explaining what could motivate an academic institute to embrace TQM into its process; examining to the extent to which TQM is relevant and matching with education; and what may hinder the successful application of TQM in education. However, in general, it can be said that in order to make TQM successful, it is essential to create a quality culture, i.e. a shift is needed from traditional management culture to a total quality culture. According to Deming, TQM is a management philosophy that requires a radical cultural change from traditional management to continuous improvement management style in an organization [5]. A similar thought is also echoed by Sallis; he mentions that it (TQM) requires a change of culture; it requires a change of attitudes and working methods, as well as a change in institutional management [61]. A quality culture is a system of shared values, beliefs, and norms that focuses on delighting customers and continuously improving the quality of products and services. Quality culture can foster the TQM principles like continuous improvement, open communication, fact-based problem solving and decision making, etc. In addition, academic institutions should adopt a more customer oriented approach in dealing with their student. Conventional teacherstudent relationship is no more value adding to anyone. It is necessary to spread professional management practices in the educational institutions. There is a wide range of tools and techniques available in TQM. Random selection of TQM tools, techniques and concepts shall not provide any meaningful benefit. Instead, it is wise to choose those tools and techniques which are consistent with an academic institution. The process toward total quality is a slow and steady process; it needs time, this change can be achieved with patience, cooperation, and assistance. Furthermore, each institution should be a learning organization focusing on the individual development of the learner, as well as the empowerment of all staff as emphasized by Spanbauer [13].

\section{References}

[1] Lunenburg, F.C. (2010) Total Quality Management Applied to Schools. Schooling, 1, 1-9.

[2] Koslowski, A.F. (2006) Quality and Assessment in Context: A Brief Review. Quality Assurance in Education, 14, 277-288. https://doi.org/10.1108/09684880610678586

[3] Crosby, P.B. (1979) Quality Is Free. New American Library, New York.

[4] Short, P.J. and Rahim, M.A. (1995) Total Quality Management in Hospitals. Total Quality Management, 6, 255-263. https://doi.org/10.1080/09544129550035422

[5] Deming, W.E. (1986) Out of the Crisis. MIT Press, Cambridge. 
[6] Yang, C.C. (2005) An Integrated Model of TQM and GE-Six Sigma. International Journal of Six Sigma and Competitive Advantage, 1, 97-105.

https://doi.org/10.1504/IJSSCA.2004.005280

[7] Goetsch, D.L. and Davis, S. (1994) Introduction to Total Quality: Quality, Productivity, Competitiveness. Macmillian College Publishing Co., New York.

[8] Vinni, R. (2011) Total Quality Management and Paradigms of Public Administration. International Public Review, 8, 15-23.

[9] Witcher, B.J. (1990) Total Marketing: Total Quality and Marketing Concept. The Quarterly Review of Marketing (Winter), 12, 55-61.

[10] Oakland, J. (2003) Total Quality Management: Text with Cases. Elsevier, Butterworth Heinemann, Oxford.

[11] Escrig, A.B. (2004) TQM as a Competitive Factor: A Theoretical and Empirical Analysis. International Journal of Quality \& Reliability Management, 21, 612-637. https://doi.org/10.1108/02656710410542034

[12] Kumar, V., Choisne, F., Grosbois, D. and Kumar, U. (2009) Impact of TQM on Company's Performance. International Journal of Quality \& Reliability Management, 26, 23-37. https://doi.org/10.1108/02656710910924152

[13] Spanbauer, S.J. (1995) Reactivating Higher Education with Total Quality Management: Using Quality and Productivity Concepts, Techniques and Tools to Improve Higher Education. Total Quality Management, 6, 519-537.

[14] Yudof, M.G. and Busch-Vishniac, I. (1996) Total Quality: Myth or Management in Universities. Change, 28, 19-27. https://doi.org/10.1080/00091383.1996.9937148

[15] Anderson, K. and Zemke, R. (1998) Delivering Knock Your Socks off Service. Amacom, New York.

[16] Lee, M.C. and Hwan, I.S. (2005) Relationships among Service Quality, Customer Satisfaction and Profitability in the Taiwanese Banking Industry. International Journal of Management, 22, 635-648.

[17] Wani, I.A. and Mehraj, H.K. (2014) Total Quality Management in Education: An Analysis. International Journal of Humanities and Social Science Invention, 3, 71-78.

[18] Schargel, F.P. (1994) Transforming Education through Total Quality Management: A Practitioner's Guide. The Leadership Management Series, Princeton.

[19] Gaither, N. (1996) Production and Operations Management. Duxbury Press, Cincinnati.

[20] Yusuf, S.M. and Aspinwall, E. (2000) TQM Implementation Issue: Review and Case Study. International Journal of Operation and Production Management, 20, 634-655. https://doi.org/10.1108/01443570010321595

[21] Ishikawa, K. (1985) What Is Total Quality Control? The Japanese Way. Translated by Lu, D.J., Prentice-Hall, Englewood Cliffs, New Jersey.

[22] Zakuan, N., Muniandy, S., Mat Saman, M.Z., Ariff, M.S.M., Sulaiman, S. and Jalil, R.A. (2012) Critical Success Factors of Total Quality Management Implementation in Higher Education Institution: A Review. International Journal of Academic Research in Business and Social Sciences, 2, 19-32.

[23] Michael, R.K., Sower, V.E. and Motwani, J. (1997) A Comprehensive Model for Implementing Total Quality Management in Higher Education. Benchmarking for Quality Management and Technology, 4, 104-120. https://doi.org/10.1108/14635779710174945

[24] Meirovich, G. and Romar, E.J. (2006) The Difficulty in Implementing TQM in Higher Education Instruction-The Duality of Instructor/Student Roles. Quality Assurance in Educa- 
tion, 14, 324-337. https://doi.org/10.1108/09684880610703938

[25] Sirvanci, M.B. (2004) Critical Issues for TQM Implementation in Higher Education. The TQM Magazine, 16, 382-386. https://doi.org/10.1108/09544780410563293

[26] Helms, S. and Key, C.H. (1994) Are Students More than Customers in the Classroom? Quality Progress, 27, 97-99.

[27] Venkatraman, S. (2007) A Framework for Implementing TQM in Higher Education Programs. Quality Assurance in Education, 15, 92-112. https://doi.org/10.1108/09684880710723052

[28] James, V. and James, L. (1998) Higher Education and Total Quality Management. Total Quality Management \& Business Excellence, 9, 659-668. https://doi.org/10.1080/0954412988136

[29] Deming, W.E. (1993) Total Quality Management in Higher Education. Management Services, $35,18-20$.

[30] Tribus, M. (1993) Why Not Education: Quality Management in Education. Journal for Quality and Participation, 16, 12-21.

[31] Peak, M.H. (995) TQM Transforms the Classroom. Management Reviews, 84, 13-19.

[32] Eriksen, S.D. (1995) TQM and the Transformation from an Elite to a Mass System of Higher Education in the UK. Quality Assurance in Education, 3, 14-29.

https://doi.org/10.1108/09684889510146795

[33] Dobyns, L. and Crawford-Mason, C. (1994) Thinking about Quality: Progress, Wisdom, and the Deming philosophy. Random House, New York.

[34] De Jager, H.J. and Nieuwenhuis, F.J. (2005) Linkages between Total Quality Management and the Outcomes-Based Approach in an Education Environment. Quality in Higher Education, 11, 251-260. https://doi.org/10.1080/13538320500354150

[35] Murad, A. and Rajesh, K.S. (2010) Implementation of Total Quality Management in Higher Education. Asian Journal of Business Management, 2, 9-16.

[36] Koch, J.V. and Fisher, J.L. (1998) Higher Education and Total Quality Management. Total Quality Management, 9, 659-668. https://doi.org/10.1080/0954412988136

[37] Houston, D. (2007) TQM and Higher Education: A Critical Systems Perspective on Fitness for Purpose. Quality in Higher Education, 13, 3-17. https://doi.org/10.1080/13538320701272672

[38] Dill, D. (1995) Through Deming's Eyes: A Cross-National Analysis of Quality Assurance Policies in Higher Education. Quality in Higher Education, 1, 95-110. https://doi.org/10.1080/1353832950010202

[39] Harvey, L. (1995) Beyond TQM. Quality in Higher Education, 1, 123-146. https://doi.org/10.1080/1353832950010204

[40] Peat, M., Taylor, C.E. and Franklin, S. (2005) Re-Engineering of Undergraduate Science Curricula to Emphasize Development of Lifelong Learning Skills. Innovations in Education and Teaching International, 42, 135-146. https://doi.org/10.1080/14703290500062482

[41] Williams, G. (1993) Total Quality Management in Higher Education: Panacea or Placebo? Higher Education, 25, 229-237. https://doi.org/10.1007/BF01383852

[42] Arcaro, J. (1995) Quality in Education: An Implementation Handbook. St. Lucie Press, Delray Beach, Florida.

[43] Bayraktar, E., Tatoglu, E. and Zaim, S. (2008) An Instrument for Measuring the Critical Factors of TQM in Turkish Higher Education. Total Quality Management and Business EXcellence, 19, 551-574. https://doi.org/10.1080/14783360802023921 
[44] Quinn, A., Lemay, G., Larsen, P. and Johnson, D.M. (2009) Service Quality in Higher Education. Total Quality Management and Business Excellence, 20, 139-152. https://doi.org/10.1080/14783360802622805

[45] Sousa, R. and Voss, C.A. (2001) Quality Management: Universal or Context Dependent? Production and Operations Management, 10, 383-404. https://doi.org/10.1111/j.1937-5956.2001.tb00083.x

[46] Sousa, R. and Voss, C.A. (2008) Contingency Research in Operations Management Practices. Journal of Operations Management, 26, 697-713. https://doi.org/10.1016/j.jom.2008.06.001

[47] Seymour, D.T. (1991) TQM on Campus: What the Pioneers are Finding. AAHE Bulletin, 44, 10-13.

[48] Birnbaum, R. and Deshotels, J. (1999) Has the Academy Adopted TQM? Planning for Higher Education, 28, 29-37.

[49] Brinbaum, R. (2000) Management Fads in Higher Education: Where They Come from, What They Do, Why They Fail. Jossey-Bass Inc., San Fransisco.

[50] Massy, W.F. (2003) Honoring the Trust: Quality and Cost Containment in Higher Education. Anker Publication, Bolton.

[51] Rosa, M.J., Sarrico, C.S. and Amaral, A. (2012) Implementing Quality Management Systems in Higher Education Institutions, Quality Assurance and Management. In: Savsar, M., Ed., InTech JanezaTrdine, Rijeka, 129-146.

[52] Brown, M.G., Hitchcock, D.E. and Willard, M.L. (1994) Why TQM Fails and What to Do About It. Irwin, Burr Ridge.

[53] Sarrico, C.S., Rosa, M.J., Teixeira, P.N. and Cardoso, M.F. (2010) Assessing Quality and Evaluating Performance in Higher Education: Worlds Apart or Complementary Views? Minerva, 48, 35-54. https://doi.org/10.1007/s11024-010-9142-2

[54] Houston, D. (2008) Rethinking Quality and Improvement in Higher Education. Quality Assurance in Education, 16, 61-79. https://doi.org/10.1108/09684880810848413

[55] Ali, M. and Shastri, R.K. (2010) Implementation of Total Quality Management in Higher Education. Asian Journal of Business Management, 2, 9-16.

[56] Youssef, M.A., Libby, P., AI-Khafaji, A. and Sawyer Jr., G. (1998) TQM Implementation Barriers in Higher Education. International Journal of Technology Management, 16, 584593.

[57] Koch, J.V. (2003) TQM: Why Is Its Impact in Higher Education So Small? The TQM Magazine, 15, 325-333. https://doi.org/10.1108/09544780310487721

[58] Rosa, M.J. and Amaral, A. (2007) A Self-Assessment of Higher Education Institutions from the Perspective of the TQM Excellence Model. In: Westerheijen, D.F., Stensaker, B. and Rosa, M.J., Eds., Quality Assurance in Higher Education: Trends in Regulation, Translation and Transformation, Vol. 20, Springer, Dordrecht, 181-207.

[59] Dale, B.G., Van der Wiele, T. and Van Iwaarden, J. (2007) Managing Quality. Blackwell Publishing, Oxford.

[60] Kosgei, J.M. (2014) Challenges Facing the Implementation of Total Quality Management in Secondary Schools: A Case of Eldoret East District, Kenya. Global Journal of Human Resource Management, 3, 12-18.

[61] Sallis, E. (2002) Total Quality Management in Education. Kogan-Page, London. 
Submit or recommend next manuscript to SCIRP and we will provide best service for you:

Accepting pre-submission inquiries through Email, Facebook, LinkedIn, Twitter, etc. A wide selection of journals (inclusive of 9 subjects, more than 200 journals)

Providing 24-hour high-quality service

User-friendly online submission system

Fair and swift peer-review system

Efficient typesetting and proofreading procedure

Display of the result of downloads and visits, as well as the number of cited articles

Maximum dissemination of your research work

Submit your manuscript at: http://papersubmission.scirp.org/

Or contact jss@scirp.org 